\section{Agrobacterium-mediated genetic transforma- tion of a tropical elite maize line}

\author{
Rafaeli Aparecida Vieira de Souza ${ }^{1}$, Meire de Cássia Alves ${ }^{2}$, \\ Newton Portilho Carneiro², Beatriz de Almeida Barros², Aluízio \\ Borém $^{1}$ and Andréa Almeida Carneiro ${ }^{2^{*}}$
}

\begin{abstract}
The efficiency of maize transformation mediated by Agrobacterium tumefaciens is influenced by various factors. The aim of this study was to test the effect of different concentrations of N6 salts $150 \%$ - half strength, and $100 \%$ - full strength) in the infection and cocultivation media on genetic transformation efficiency of the $L 3$ tropical elite maize line. Immature embryos were transformed via A. tumefaciens harboring the binary vector pTF102 containing the genes uidA and BAR under control of the CaMV35S promoter. The efficiency of the transgenic events produced was $3 \%$ for full strength and $1.1 \%$ for half strength N6 salts. Although under a lower concentration of salts, GUS expression was stronger; under this concentration, regeneration was less efficient. Thus, the results showed that the presence of $100 \%$ N6 salts in the infection and cocultivation media favored genetic transformation of the $L 3$ maize inbred line mediated by $A$. tumefaciens.
\end{abstract}

Key words: Immature embryos, salt concentration, somatic embryogenesis, Zea mays.

\section{INTRODUCTION}

Brazil produced 84.7 million tons of maize on 15.7 million hectares in 2015 (Conab 2016) and it is estimated that $80 \%$ of the maize harvested is genetically modified. So far, no Brazilian company has implemented a pipeline for transformation and commercial release of tropical maize lines. Governmental and private agricultural institutions in Brazil have been conducting investigations related to the adaptation of maize to biotic and abiotic stresses aiming at an increase in yield, and genetic transformation of tropical maize lines may have a major impact on the development of new products based on this knowledge. One of the main obstacles to application of this technology to tropical maize lines is the selection of germplasm responsive to regeneration in tissue culture and infection by Agrobacterium.

The regeneration pathway most used for transgenic maize cells is somatic embryogenesis, which was first described by Green and Phillips (1975) using immature maize embryos as explants. Maize embryogenic cultures have two predominant forms of callus, Type I and Type II, which differ primarily in their regeneration efficiency over an extended time in a culture medium. Although both calli are capable of plant regeneration, cultures formed by the Type II callus grow faster; can be maintained for a longer period of time, and form a larger
Crop Breeding and Applied Biotechnology 17: 133-140, 2017 Brazilian Society of Plant Breeding. Printed in Brazil http://dx.doi.org/10.1590/198470332017v17n2a20 


\section{RAV Souza et al.}

number of somatic embryos. These characteristics favor the selection and regeneration of transgenic plants (Johnson and McCuddin 2009). The occurrence of the Type II friable embryogenic callus is not so common, only a limited number of maize genotypes are able to express this phenotype, especially the hybrid Hi-II (Armstrong and Green 1985). Because of this characteristic, $\mathrm{Hi}-\mathrm{Il}$ is one of the most used genotypes in genetic transformation protocols. However, it has low agronomic performance (Que et al. 2014). The transgene can be transferred to elite varieties using backcrosses; but this process is long, and unwanted traits can be transmitted together with the gene of interest.

Regeneration and transformation are largely influenced by the explant type and the composition of the culture medium (Armstrong and Green 1985, Songstad et al. 1991, Bohorova et al. 1995). To date, immature zygotic embryos are the explant with the highest regeneration efficiency, and competence for infection by $A$. tumefaciens and generation of transgenic plants (Frame et al. 2006, Vega et al. 2008).

The N6 (Chu et al. 1975) and MS (Murashige and Skoog 1962) salts are widely used for in vitro cultivation and genetic transformation of maize (Ishida et al. 1996, Frame et al. 2006, Vega et al. 2008, Li et al. 2015). Embryogenic calli are normally formed when immature zygotic maize embryos are cultured in these basal media supplemented with auxins, such as 2,4-D or Dicamba (Green and Phillips 1975, Armstrong and Green 1985, Frame et al. 2006, Petrillo et al. 2008).

The salt content of the culture medium appears to be an important factor capable of influencing the efficiency of transformation mediated by Agrobacterium. Although the transformation improvement mechanism is not clear, the use of low salt contents through the infection and cocultivation stages has been shown to improve the transfer of T-DNA (Fry et al. 1987, Cheng et al. 1997, Armstrong and Rout 2001, Zhang et al. 2002, Paz et al. 2004, Vega et al. 2008).

An increase in T-DNA transfer efficiency was also achieved by supplementation of the infection and cocultivation media with antioxidants or anti-necrotic mixtures. Cysteine, dithiothreitol (DTT), polyvinyl pyrrolidone, and ascorbic acid (Perl et al. 1996, Olhoft and Somers 2001, Paz et al. 2004, Frame et al. 2006, Mishra et al. 2014) are antioxidants that have been used to increase the potential of Agrobacterium to infect tissues by inhibiting the antimicrobial exudates produced by plant cells during the infection and cocultivation stages and/or by preventing the occurrence of necrosis in the plant tissue (Gupta 2010).

The selection of genotypes to obtain transgenic maize plants focuses on in vitro regeneration capacity and the possibility of infection by Agrobacterium. An ideal genotype for the production of commercial transgenic plants, in addition to the features mentioned above, must have excellent agronomic performance. The L 3 tropical elite maize inbred line from Embrapa maize germplasm has all these desirable characteristics, and the aim of this study was to identify culture media that contribute most to its efficiency of transformation by Agrobacterium tumefaciens.

\section{MATERIAL AND METHODS}

\section{Plant Material}

The L3 tropical maize inbred line from Embrapa Milho e Sorgo (Embrapa Maize and Sorghum), located in the state of Minas Gerais, Brazil, was used for the transformation experiments. For embryo extraction, ears pollinated for 10-15 days were surface sterilized in half-strength liquid commercial bleach ( $2.5 \%$ sodium hypoclorite) and $0.01 \%$ Tween 20 for 30 minutes and then rinsed three times with sterile distilled water. In all experiments, immature embryos from 1.5 to $2.2 \mathrm{~mm}$ from the same ear were equally distributed among treatments to minimize variation.

\section{Genetic construct and Agrobacterium tumefaciens preparation}

The A. tumefaciens used was the disarmed strain EHA101 (Hood et al. 1986) harboring the binary plasmid pTF102 (Paz et al. 2004). The bacterial resistance marker in pTF102 is spectinomycin. This plasmid also contains the phosphinothricin acetyltransferase (BAR) gene as a plant selection marker and the reporter gene uidA, both controlled by the CaMV35S promoter. The uidA gene contains an intron to prevent its expression in Agrobacterium cells (Paz et al. 2004).

A. tumefaciens was cultivated in Yeast Extract Peptone (YEP) solid medium ( $5 \mathrm{~g} \mathrm{~L}^{-1}$ yeast extract, $10 \mathrm{~g} \mathrm{~L}^{-1}$ peptone, $5 \mathrm{~g}$ $\mathrm{L}^{-1} \mathrm{NaCl}, 15 \mathrm{~g} \mathrm{~L}^{-1}$ Bacto-agar, $\mathrm{pH}$ 6.8) containing $100 \mathrm{mg} \mathrm{L}^{-1}$ spectinomycin and $50 \mathrm{mg} \mathrm{L}^{-1}$ kanamycin (for EHA 101) for three days at $19{ }^{\circ} \mathrm{C}$. Two hours prior to transformation, Agrobacterium was resuspended at $\mathrm{OD}_{550} 0.3$ to 0.4 in two different 
Agrobacterium-mediated genetic transformation of a tropical elite maize line

Table 1. Culture media used for genetic transformation of immature embryos from the L3 tropical inbred maize line mediated by Agrobacterium tumefaciens

\begin{tabular}{|c|c|}
\hline Medium & Composition \\
\hline $\begin{array}{l}\text { Infection } \\
\text { Medium } 1^{1}\end{array}$ & 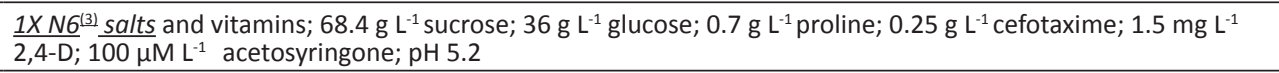 \\
\hline $\begin{array}{l}\text { Infection } \\
\text { Medium } 2^{2}\end{array}$ & $\begin{array}{l}1 / 2 X \mathrm{~N} 6 \text { salts and vitamins; } 68.4 \mathrm{~g} \mathrm{~L}^{-1} \text { sucrose; } 36 \mathrm{~g} \mathrm{~L}^{-1} \text { glucose; } 0.7 \mathrm{~g} \mathrm{~L}^{-1} \text { proline; } 0.25 \mathrm{~g} \mathrm{~L}^{-1} \text { cefotaxime; } 1.5 \mathrm{mg} \mathrm{L}^{-1} \\
2,4-\mathrm{D} ; 100 \mu \mathrm{M} \mathrm{L}^{-1} \text { acetosyringone; } 0.5 \mathrm{~g} \mathrm{~L}^{-1} \text { 2-(N-Morpholino)ethanesulfonic acid (MES); } 0.85 \mathrm{mg} \mathrm{L}^{-1} \text { silver nitrate; } \\
\text { pH 5.2 }\end{array}$ \\
\hline Cocultivation Medium $1^{1}$ & 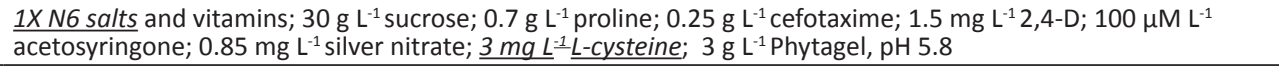 \\
\hline Resting & $\begin{array}{l}1 \mathrm{X} \text { N6 salts and vitamins; } 30 \mathrm{~g} \mathrm{~L}^{-1} \text { sucrose; } 0.7 \mathrm{~g} \mathrm{~L}^{-1} \text { proline; } 0.5 \mathrm{~g} \mathrm{~L}^{-1} \mathrm{MES} ; 0.85 \mathrm{mg} \mathrm{L}^{-1} \text { silver nitrate; } 0.25 \mathrm{~g} \mathrm{~L}^{-1} \text { cefo- } \\
\text { taxime; } 10 \mathrm{mg} \mathrm{L} \text { L- } 2 \text { - } 3 \mathrm{~g} \mathrm{~L}^{-1} \text { Phytagel, } \mathrm{pH} 5.8\end{array}$ \\
\hline Selection I & $\begin{array}{l}1 \mathrm{X} \mathrm{N6} \text { salts and vitamins; } 30 \mathrm{~g} \mathrm{~L}^{-1} \text { de sucrose; } 0.7 \mathrm{~g} \mathrm{~L}^{-1} \text { proline; } 0.5 \mathrm{~g} \mathrm{~L}^{-1} \mathrm{MES} ; 0.25 \mathrm{~g} \mathrm{~L}^{-1} \text { cefotaxime; } 10 \mathrm{mg} \mathrm{L}^{-1} 2,4-\mathrm{D} ; \\
1.5 \mathrm{mg} \mathrm{L}^{-1} \text { bialaphos; } 3 \mathrm{~g} \mathrm{~L}^{-1} \text { Phytagel, } \mathrm{pH} 5.8\end{array}$ \\
\hline Selection II & Selection I supplemented with $3.0 \mathrm{mg} \mathrm{L}^{-1}$ bialaphos \\
\hline
\end{tabular}

infection media, infection medium 1 and infection medium 2 (Table 1), supplemented with $100 \mu \mathrm{M}$ of acetoseringone and incubated at $22^{\circ} \mathrm{C}$ and $100 \mathrm{rpm}$.

\section{Genetic transformation of immature maize embryos of the L3 inbred line mediated by Agrobacterium tumefaciens}

Genetic transformations of maize were performed using culture media 1 and 2 according to Frame et al. (2006) and Vega et al. (2008), respectively, with few modifications. All culture media are described in Table 1. Embryos were placed in $1.5 \mathrm{ml}$ Eppendorf tubes containing $1.0 \mathrm{ml}$ of infection medium (1 or 2) supplemented with $100 \mu \mathrm{M}$ of acetosyringone and washed twice with the same medium. After removing the final wash, $1 \mathrm{ml}$ of the Agrobacterium suspension, prepared using infection medium 1 or 2 , was added for 5 min to tubes containing embryos. Then embryos from infection medium 1 were placed in cocultivation medium 1, and embryos from infection medium 2 were placed in cocultivation medium 2, with the axis in contact with the medium, and incubated at $20^{\circ} \mathrm{C}$ for five days in the dark. After the incubation period, the embryos were transferred to a resting medium at $28^{\circ} \mathrm{C}$ for two weeks in the dark. Resting, selection I and II, maturation, and germination media were the same for the embryos initially infected and cocultivated on medium 1 or 2.

Selection was initiated with the transfer of all embryos to selection medium I supplemented with $1.5 \mathrm{mg} \mathrm{L}^{-1}$ bialaphos (tripeptide L-phosphinothricyl-L-alanyl-L alanine) (Thompson et al. 1987) (Goldbio.com / St. Louis, MO, USA) for two weeks. Transfer to a new selection medium was repeated 2-3 times until the onset of embryogenic calli with vigorous growth. After that, these calli were transferred to selection medium II supplemented with $3 \mathrm{mg} \mathrm{L}^{-1}$ bialaphos, where they remained for 14 days. Selected calli were transferred to a maturation medium for 2-4 weeks at $27^{\circ} \mathrm{C}$. Mature embryos with a white opaque and dry appearance were grown on a germination medium for 2-4 weeks. Seedlings around $5 \mathrm{~cm}$ in length and with a well-developed root system were transferred to soil. After acclimatization, the plants were treated with $500 \mathrm{mg} \mathrm{L}^{-1}$ Finale $^{\odot}$ to ensure that all events in the greenhouse express the BAR gene. The presence of the BAR gene was also screened in T1 and T2 progenies by spraying germinated seedlings at 14 days post emergence with 500 $\mathrm{mg} \mathrm{L}^{-1}$ Finale $^{\odot}$.

\section{GUS histochemical analyses}

The expression of $\beta$-glucuronidase (GUS) was assessed by histochemical analyses (Jefferson et al. 1987) in 25 embryos after the cocultivation and resting stages and in 10 embryogenic calli after the selection process. Embryos or calli were immersed in a solution containing $1 \mathrm{mM} 5$-bromo-4-chloro-3-indolyl $\beta$-D glucuronide, $50 \mathrm{mM}$ phosphate buffer $\mathrm{pH}$ $6.8,20 \%$ methanol, and $1 \%$ Triton X-100, incubated at $37^{\circ} \mathrm{C}$ for $16-24$ hours. The presence or absence of blue staining was assessed using a Zeiss Axio Zoom V16 stereomicroscope. Embryos or calli that showed at least one blue spot were 


\section{RAV Souza et al.}

considered positive for expression of the uidA gene.

\section{Molecular analyses of transgenic events}

The presence of the genetic construct was confirmed by PCR using genomic DNA from leaves of transgenic (T0) events (Saghai-Maroof et al. 1984) and primes for the BAR gene (5'AGA CAC AAC ATG GTC CC3' and 5'TGC ATC ACC GTC AAC CAC3'), which amplify a fragment of $407 \mathrm{bp}$. The $20 \mu \mathrm{L}$ PCR reaction contained $0.1 \mathrm{U}$ of Taq DNA Polymerase (Invitrogen /SP, Brazil), $2.5 \mathrm{mM} \mathrm{MgCl}, 200 \mu \mathrm{M}$ dNTPs, $1 \mathrm{X}$ buffer, and $20 \mathrm{ng}$ genomic DNA. Amplification was performed in a Veriti Thermal Cycler (Applied Biosystems, Foster City, CA), using an initial denaturation at $94{ }^{\circ} \mathrm{C}$ for 2 minutes, 35 cycles of $94{ }^{\circ} \mathrm{C}$ for 20 seconds, $60{ }^{\circ} \mathrm{C}$ for 30 seconds, and $72{ }^{\circ} \mathrm{C}$ for 90 seconds, and a final extension at $72{ }^{\circ} \mathrm{C}$ for 5 minutes. The PCR products were visualized in 1\% agarose gels, stained with 1:100 dilution GelRed Stain Nucleic Acid (Biotium / Uniscience /SP, Brazil).

To estimate the copy number of transgene insertions in the TO events, a proprietary single copy transgenic maize plant MSALTSBL22 (Barros et al. 2011) and L3 line were used as a reference sample and negative control, respectively. The transgene used was the BAR gene (BAR F: 5'ACA GCG ACC ACG CTC TTG A-R3' / BAR R: 5'GCT CTA CAC CCA CCT GCT GAA3') and the reference was the adh1 gene (Adh1F: 5' GTA ACA TGC TCC AGC ACT GCT ATT3' / Adh1R: 5'TCG TAT GAT GTG TTC AGC CAG ACT 3') (Ingham et al. 2001). The qPCR reactions were carried out in $10 \mu$ reaction mixtures containing 50 ng template DNA, Fast SYBR Green Master Mix 1X (Applied Biosystems, Foster City, CA, USA), and $0.5 \mu \mathrm{M}$ primers.

For expression data, total RNA was extracted from fresh leaves using the RNeasy Plant Mini Kit (Qiagen, São Paulo, SP, Brazil) according to manufacturer's instructions. First-strand cDNA was synthesized using the High Capacity cDNA Reverse Transcription Kit (Life Technologies, São Paulo, SP, Brazil). Expression of the uidA reporter (GUSF: 5' CGT GGC AAA GGA TTC GAT AA 3' / GUSR: 5' CTC TTC AGC GTA AGG GTA ATG 3') and BAR genes were assessed using a SYBR Green-based assay and actin gene as a reference gene (ActF: 5' TCC TGA CAC TGA AGT ACC CGA TTG3' / ActR: 5'-AGT TCG TTG TAG AAG GTG TGA TGC C3'). The qPCR reaction conditions were the same as described above.

All quantitative analyses were carried out in a 7500 Fast Real Time PCR System (Applied Biosystems, Foster City, CA, USA) using the comparative CT method, $\triangle \Delta C T$ (Livak and Schmittgen 2001). Each biological sample was a bulk of leaves from ten TO plants, with three technical replicates each.

\section{Statistical analysis}

The two media tested for infection and cocultivation were evaluated by comparing the percentage of GUS positive embryos or calli after cocultivation, resting, and selection, and by the number of transgenic callus and regenerated events obtained. The percentage of positive embryos or calli were calculated by multiplying the number of embryos or calli that had at least one blue spot by 100 and dividing this result by the total number of embryos or calli analyzed. The experimental design was completely randomized, with four replicates (200 embryos/replicate). For analysis of variance, the software R (R Foundation 2015) was used, and means were compared by the Tukey test at $5 \%$ probability.

\section{RESULTS AND DISCUSSION}

In the present study, the uidA gene was used as a reporter to compare the efficiency of gene transfer from $A$. tumefaciens to cells of immature embryos of the L3 tropical maize inbred line, after the cocultivation and resting stages, on media containing full $(100 \%)$ and half $(50 \%)$ strength N6 salts. Usually, conditions which allow a high level of expression of this reporter gene are associated with a high rate of production of transgenic events (Hiei at al. 1994, Petrillo et al. 2008, Vega et al. 2008).

After cocultivation with Agrobacterium EHA 101 harboring the binary vector pTF102, over 70\% of L3 immature embryos were infected and capable of transiently expressing the uidA gene, regardless of the coculture medium used. A higher number of embryos was able to express the uidA gene when infection and cocultivation used full strength N6 salts (medium 1) in comparison with the half strength salts (medium 2) (Table 2). However, the histochemical assay revealed that GUS expression was stronger in the embryos maintained on half strength salts (medium 2) (Figure $1 \mathrm{~A}$ and B). Although expression of the uidA gene has not been quantified, the expression pattern shown in Figures $1 \mathrm{~A}$ and $B$ was always repeated in all maize transformations performed. Histochemical analysis comparing infection and 
Agrobacterium-mediated genetic transformation of a tropical elite maize line

Table 2. Comparison between culture medium 1 and 2 used to transform immature embryos of the L3 tropical maize inbred line.

\begin{tabular}{|c|c|c|c|}
\hline Parameter & Medium $1^{1}$ & Medium $\mathbf{2}^{2}$ & CV (\%) \\
\hline \multicolumn{4}{|l|}{ Histochemical uidA test after } \\
\hline Cocultivation (\%) & $89.66 \mathrm{a}$ & $74.00 \mathrm{~b}$ & 5.21 \\
\hline Resting (\%) & $74.66 \mathrm{a}$ & $32.00 \mathrm{~b}$ & 20.47 \\
\hline Selection II (\%) & $53.00 \mathrm{a}$ & $24.66 \mathrm{~b}$ & 14.83 \\
\hline \multicolumn{4}{|l|}{ Transgenic events } \\
\hline Number of resistant calli & $18.75 \mathrm{a}$ & $9.50 \mathrm{~b}$ & 16.79 \\
\hline
\end{tabular}

Means followed by the same letter in the line do not differ at $5 \%$ probability by the Tukey test

${ }^{1} 100 \%$ and ${ }^{2} 50 \%$ N6 salt concentration

${ }^{3}$ Regenerated transgenic events $\times 100 /$ Immature embryos.

cocultivation media 1 and 2 was conducted simultaneously and with the same solutions, thus ruling out any artifacts that could interfere with a differential expression of the reporter gene. Ke et al. (2002) report that transient expression of GUS in immature barley embryos infected with $A$. tumefaciens harboring the uidA gene increased 10 times when conducted in a medium containing $1 / 10$ strength MS salts.

After the resting and selection II stage (Table 2), a higher number of embryos expressing GUS originated from medium 1 , confirming that for the L3 maize line, the full strength N6 salt content was more efficient. Most of the embryos kept on half strength N6 salt (medium 2) developed poorly afterward. Vega et al. (2008), working on the transformation efficiency of $\mathrm{Hi}-\mathrm{II}$, reported that even though low strength salt (10\%) improves gene transfer, it decreases the embryogenic response of the explant. The same developmental pattern was observed by Du et al. (2010); explants maintained on media supplemented with $10 \%$ and $30 \%$ salt displayed GUS staining, but most of them did not develop further and died. Even though half strength N6 salt enabled optimum T-DNA transfer, it had damaging effects on the embryogenic aptitude of immature maize embryos.

Another contrasting difference between these media is the presence of cysteine alone or cysteine plus DTT, in the infection and cocultivation media 1 and 2 , respectively. The higher concentration of antioxidants present in medium 2 might have contributed to more effective Agrobacterium infection by inhibiting defense mechanisms such as the production of reactive oxygen species (ROS) by the immature embryos infected (Gupta 2010). This intensification in infection may have compromised embryo regeneration capability. Ishida et al. (2007) showed that immature embryos expressing higher levels of the uidA reporter gene after the cocultivation stage were not the best ones to regenerate transgenic maize plants.

A total of 106 calli that survived to the selection II stage grew rapidly and had a friable appearance and light yellow color (Figure 1C and D). Of this total, 61 were from the infection and cocultivation medium 1, and 45 from medium 2; all calli selected were transferred to the maturation medium. Maturation occurred unevenly within the period of 20 to 45 days, regardless of the media used for infection and cocultivation. Only $42.62 \%$ and $20 \%$ of
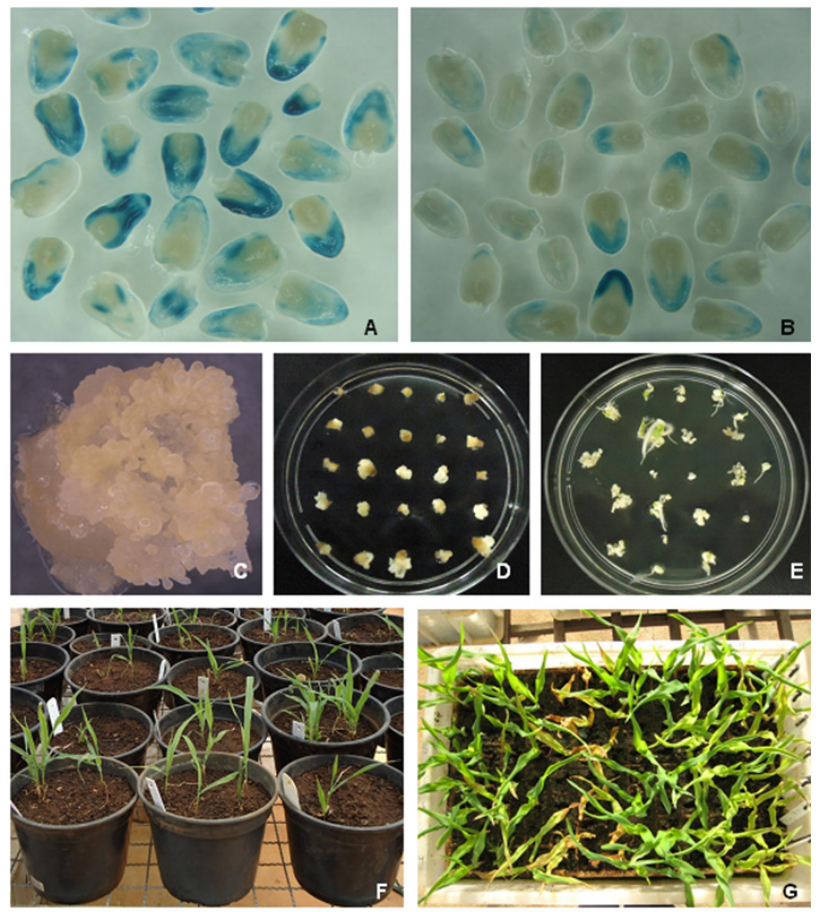

Figure 1. Genetic transformation of the $L 3$ tropical maize inbred line. (A - B) Histochemical analysis of uidA gene expression; (A) infection with $50 \%$ (medium 2) and (B) $100 \%$ (medium 1) N6 salts; (C - D) Embryogenic callus after 5 weeks under bialaphos selection; (E) Selected calli on regeneration medium; (F) Plantlets in the greenhouse; and (G) T2 plants sprayed with Finale ${ }^{\odot}$. 
calli from medium 1 and 2 matured, respectively. Mature calli were transferred to the germination medium, and at least three plants from each event were transferred and acclimatized in the greenhouse (Figure $1 \mathrm{E}$ and F). Plants grown in the greenhouse had normal structure, good tassel quality, and set variable numbers of seeds.

Stable integration of the transgene into the L3 maize genome was confirmed by treatment of germinated T1 and $\mathrm{T} 2$ seeds with the herbicide Finale ${ }^{\odot}$ (Figure 1G). The number of herbicide resistant calli selected, the number of regenerated plants, and the efficiency of recovery of transgenic events using media 1 and 2 are shown in Table 2. Corroborating the results obtained for GUS expression, the total number of transgenic plants for the L3 maize line was higher when full strength N6 salt was used compared to half strength (Table 2). Half strength N6 salt may not have been effective for production of transgenic events, due to the decrease observed in the embryogenic response of the L3 embryos.

Thirty-five plants were regenerated, 26 from transformation performed using medium 1 , and 9 from medium 2; PCR amplification of genomic DNA was performed in all 35 events regenerated. Amplification of the BAR gene present in the binary vector pTF102 was observed in all transgenic events and was not detected in the non-transformed plants (Figure 2A). Real time PCR (qPCR) analyses of a subset of five putative transgenic events confirmed the expression of uidA and BAR genes (Figure 2B). As observed for the majority of transgenic plants generated by $A$. tumefaciens mediated transformation, a low copy number of the transgenes was present in the events generated (Figure $2 \mathrm{C}$ ).

The L3 tropical maize inbred line has excellent agronomic fitness and an efficient level of in vitro embryogenic capacity. In this study, it was shown that infection and cocultivation media containing full strength $\mathrm{N} 6$ salts were more efficient than half strength for the production of transgenic events from the L3 inbred tropical maize line. Improvement of the maturation process to achieve greater efficiency of plant production should be attempted, aiming at insertion of this maize line into programs of tropical transgenic maize production.

\section{ACKNOWLEDGMENTS}

Our thanks to the Research Support Foundation of the State of Minas Gerais (Fundação de Amparo a Pesquisa do Estado de Minas Gerais - Fapemig) for financial support; to the Office of Improvement for Personnel in Higher Education (Coordenação de Aperfeiçoamento Pessoal de Nível Superior/Capes) for a scholarship to RAVS.
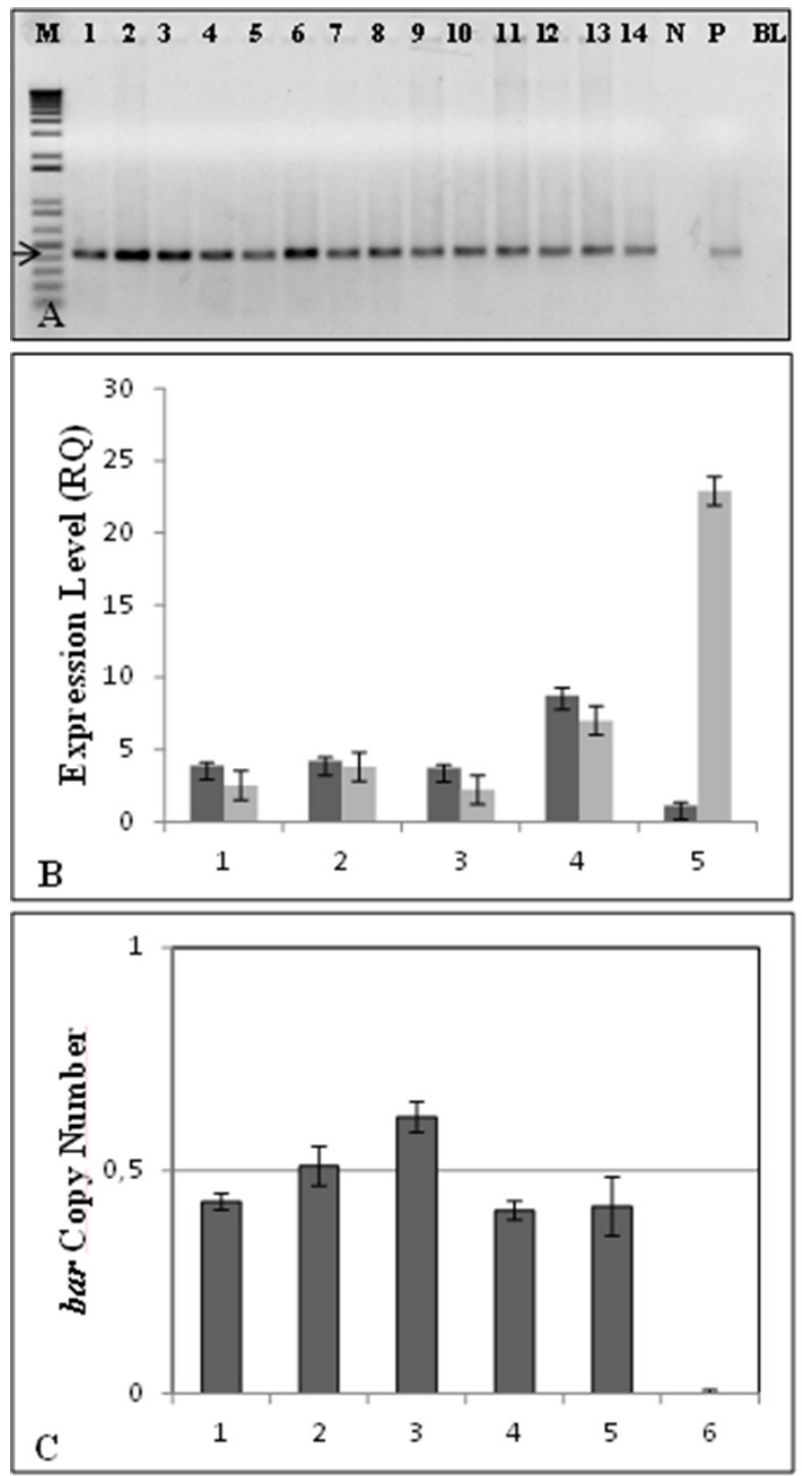

Figure 2. Molecular detection of $L 3$ transgenic events. (A) PCR amplification of genomic DNA from 14 events; (M) molecular marker $1 \mathrm{~kb}$ Plus DNA Ladder (Invitrogen/SP, Brazil); (1 to 9) regenerated plants after transformation using medium 1; (10 to 14) regenerated plants after transformation using medium 2 ; $(N)$ non-transgenic maize plant; (P) pTF102 binary vector; and (BL) reaction blank; (B) qPCR analysis of uidA (light gray bars) and BAR (dark gray bars) gene expression; (C) qPCR analysis of BAR copy number. (1, 2, and 3) events generated using medium 1; (4 and $5)$ events generated using medium 2; and (6) non-transgenic L3 plant; arrow corresponds to $407 \mathrm{bp}$. 


\section{REFERENCES}

Armstrong CL and Green CE (1985) Establishment and maintenance of friable, embryogenic maize callus and the involvement of L-proline. Planta 164: 207-214.

Armstrong CL and Rout JR (2001) A novel Agrobacterium-mediated plant transformation method. International Patent Publlication. W001/09302 A2.

Barros BA, Guimarães CT, Lana UGP, Pôssa KF, Andrade LCSS, Silva VL, Lopes FA, Carneiro AA, Carneiro NP and Magalhães JV (2011) Estimativa do número de inserções de transgenes em milho por PCR quantitativo (qPCR). Embrapa Milho e Sorgo, Sete Lagoas, 6 p. (Circular Técnica 164).

Bohorova NE, Luna B, Brito RM, Huerta LD and Hoisington DA (1995) Regeneration potential of tropical, subtropical, mid altitude, and highland maize inbreds. Maydica 40: 275-281.

Cheng M, Fry JE, Pang S, Zhou H, Hironaka CM, Duncan DR, Conner TW and Wan Y (1997) Genetic transformation of wheat mediated by Agrobacterium tumefaciens. Plant Physiology 115: 971-980.

Conab - Companhia Nacional de Abastecimento (2016) Acompanhamento da Safra Brasileira / grãos. Versão3 - Safra 2015/16 - N.8. Available at <http://www.conab.gov.br/OlalaCMS/uploads/ arquivos/16_05_10_09_03_26_boletim_graos_maio_2016.pdf>. Accessed on May 12, 2016.

Chu CC, Wang CC, Sun CS, Hsu C, Yin KC and Chu CY (1975) Establishment of an efficient medium for anther culture of rice through comparative experiments on the nitrogen source. Scientia Sinica 16: 659-668.

Du H, Wu H, Yan J and Li J (2010) Effects of basal media, salt concentrations, antioxidant supplements and co-effects on the Agrobacterium mediated transformation efficiency in maize. African Journal of Biotechnology 9: 1135-1143.

Frame BR, McMurray JM, Fonger TM, Main ML, Taylor KW, Torney FJ, Paz M M and Wang K (2006) Improved Agrobacterium-mediated transformation of three maize inbred lines using MS salts. Plant Cell Rep 25: 1024-1034.

Fry J, Barnason A and Horsch RB (1987) Transformation of Brassica napus with Agrobacterium tumefaciens based vectors. Plant Cell Reporter 6: 321-325.

Green CE and Phillips RL (1975) Plant regeneration from tissue cultures of maize. Crop Science 15: 417-421.

Gupta SD (2010) Role of free radicals and antioxidants in in vitro morphogenesis. In Gupta SD (ed) Reactive oxygen species and antioxidants in higher plants. CRC Press, Boca Raton, p. 229-247.

Hiei Y, Ohta S, Komari T and Kumashiro T (1994) Efficient transformation of rice (Oriza sativa) mediated by Agrobacterium and sequence analysis of the boundaries of the T-DNA. Plant Journal 6: 271-282.

Hood EE, Helmer GI, Fraley RT and Chilton MD (1986) The hypervirulence of Agrobacterium tumefaciens A281 is encoded in a region of pTiBo542 outside of T-DNA. Journal of Bacteriology 168: 1291-1301.
Ingham DJ, Beer S, Money S and Hansen G (2001) Quantitative real-time assay for determining transgene copy number in transformed plants. BioTechniques 31: 132-140.

Ishida V, Saito H, Ohta S, Hiei Y, Komari T and Kumashiro T (1996) High efficiency transformation of maize (Zea mays L.) mediated by Agrobacterium tumefaciens. Nature Biotechnology 6: 745-750.

Ishida Y, Hiei Y and Komari T (2007) Agrobacterium-mediated transformation of maize. Nature Protocols 2: 1614-1621.

Jefferson RA (1987) Assaying chimeric genes in plants: the GUS gene fusion system. Plant Molecular Biology Reporter 5: 387-405.

Johnson GR and McCuddin ZP (2009) Maize and the biotech industry. In Bennetzen JL and Hake S (eds) Maize handbook - volume II: Genetics and genomics. Springer Science, New York, p. 115-132.

Ke X-Y, McCormac AC, Harvey A, Lonsdale, Chen D-F and Elliott MC (2002) Manipulation of discriminatory T-DNA delivery by Agrobacterium into cells of immature embryos of barley and wheat. Euphytica 126: 333-343.

Li D, Xu H, Sun X, Cui Z, Zhang Y, Bai Y, Wang X and Chen W (2015) Differential transformation efficiency of Japonica rice varieties developed in northern China. Crop Breeding and Applied Biotechnology 15: 162-168.

Livak KJ and Schmittgen TD (2001) Analysis de relative gene expression data using real-time quantitative PCR and the $2^{-\Delta \Delta C}$ method. Method 25: 402-408.

Mishra M, Jalil SU, Sharma N and Hudedamani U (2014) An Agrobacterium mediated transformation system of guava (Psidium guajava L.) with endochitinase gene. Crop Breeding and Applied Biotechnology 14: 232-237.

Murashige T and Skoog F (1962) A revised medium for rapid growth and bioassays with tobacco tissue cultures. Plant Physiology 15: 473-497.

Olhoft PM and Somers DA (2001) Cysteine increases Agrobacteriummediated T-DNA delivery into soybean cotyledonary-node cells. Plant Cell Reporter 20: 706-711.

Paz MM, Shou H, Guo Z, Zhang Z, Banerjee AK and Wang K (2004) Assessment of conditions affecting Agrobacterium-mediated soybean transformation using the cotyledonary node explant. Euphytica 136: 167-179.

Perl A, Lotan O, Abu-Abied M and Holland D (1996) Establishment of an Agrobacterium-mediated transformation system for grape (Vitis vinifera $\mathrm{L}$.): The role of antioxidants during the grape-Agrobacterium interactions. Nature Biotechnology 14: 624-628.

Petrillo CP, Carneiro NP, Purcino AAC, Carvalho CHS, Alves JD and Carneiro AA (2008) Optimization of particle bombardment parameters for the genetic transformation of Brazilian maize inbred lines. Pesquisa Agropecuária Brasileira 43: 371-378.

Que Q, Elumalai S, Li X, Zhong H, Nalapalli S, Schweiner M, Fei X, Nuccio M, Kelliher T, Gu W, Chen Z and Chilton MDM (2014) Maize transformation technology development for commercial event 


\section{RAV Souza et al.}

generation Frontiers in Plant Science 5: 1-19.

R Foundation (2015) R: a language and environment for statistical computing. R Foundation for Statistical Computing, Vienna. Available at <http://www.R-project.org/>. Accessed on May 12, 2016.

Saghai-Maroof MA, Soliman KM, Jorgensen RA and Allard RW (1984) Ribosomal DNA spacer-length polymorphisms in barley: Mendelian inheritance, chromosomal location, and population dynamics. Proceedings National Academy of Science of the United States of America 81: 8014-8018.

Songstad DD, Armstrong CL and Petersen WL (1991) Silver nitrate increase type II callus production from immature embryos of maize inbred B73 and its derivatives. Plant Cell Reports 9: 699-702.
Thompson CJ, Movva NR, Tichard R, Crameri R, Davies JE and Lauwereys $M$ (1987) Characterization of herbicide-resistance gene bar from Streptomyces hygroscopicus: a selectable marker for plant transformation. EMBO Journal 6: 2519-2523.

Vega JM, Yu W, Kennon A, Chen X and Zhang ZJ (2008) Improvement of Agrobacterium-mediated transformation in Hi-II maize (Zea mays) using standard binary vectors. Plant Cell Reporter 27: 297-305.

Zhang S, Williams-Carrier R and Lemaux PG (2002) Transformation of recalcitrant maize elite inbreds using in vitro shoot meristematic cultures induced from germinated seedlings. Plant Cell Reporter 21: $263-270$. 